\title{
TECHNICAL EFFICIENCY ANALYSIS OF SUGAR CANE FARMING IN MALANG REGENCY, EAST JAVA, INDONESIA
}

\author{
Pujiastiti Lestari $^{1}$, Nuhfil Hanani ${ }^{2}$, Syafrial $^{2}$ \\ ${ }^{1}$ Master's Degree, Graduate Program Faculty of Agricultural Economics, University of Brawijaya, Indonesia \\ ${ }^{2}$ Departement of Socioeconomics Faculty of Agricultural Economics, University of Brawijaya, Indonesia \\ * Corresponding author: pujiastiti.757@gmail.com
}

\begin{abstract}
This study aims to analyze the factors that influence sugarcane production in Malang Regency. This reaserach uses stochastic frontier production function. The model is specified which sugarcane production is influenced by amount of seed, the labor used, the amount of fertilizer, land used in sugar cane production, the frequency of ratooncane. The results showed that factors of sugarcane farming production in Malang Regency are influenced significantly by the number of seed, amount of fertilizer used, and ratooncane frequency. The seed and amount of fertilizer used in sugarcane production have positive effect in production; however, ratooncane frequency has negative effect in production of sugarcane significantly. On the other hand, land area and labor are not statistically significant at alpha $1 \%$.
\end{abstract}

Keywords: Farming, Production Factors, Stochastic Frontier, Sugar Cane, Technical Efficiency

http://dx.doi.org/10.21776/ub.agrise.2019.019.1.1

Received 29 Juli 2018

Accepted 15 January 2019

Available online 2 March 2019

\section{INTRODUCTION}

Sugarcane is a raw material in the manufacture of sugar, including in one of the plantation sub-sector commodities which has a strategic role in the economy in Indonesia. The planting area of sugarcane is 458.26 thousand hectares in 2016, the sugar industry made from sugar cane is one of the sources of income for thousands of sugar cane farmers and workers in the sugar industry (Central Data Statistic, 2017).

Sugar is a staple of most of the Indonesian people affected by population growth. The increasing population of Indonesia every year causes an increase in demand for sugar consumption. Which increase in food demand must be balanced with the growth of food production. The increase in sugar consumption in Indonesia from year to year is seen from the amount of sugar production in the country at this time, it is felt that it has not been able to meet the needs of sugar in Indonesia.

Central Data Statistic (2015) said, that sugar production in 2010 still cannot meet the needs of sugar consumption of the Indonesian population. In 2010, national sugar production is $2,214,488$ tons, while national sugar consumption is 2,663,003 tons. The increasing in national sugar consumption occurred in 2011 which is $1.12 \%$ accompanied by an increase in national sugar production by $0.62 \%$.

National sugar demand is 5.7 million tons. It consists of 2.8 million tons of white crystalline sugar (GKP) for direct consumption of the community and 2.9 million tons of refined crystal sugar (GKR) to meet industry needs. The demands will continue to increase along with population growth, the development of the food and beverage industry, hotels and restaurants (BPS, 2017). 
Efforts made to increase national sugar production require increasing in sugar cane production and productivity in sugarcane production centers. Most of the sugarcane production is in Java especially East Java and the other production center is Lampung province

In Indonesia the biggest sugarcane production center is East Java Province. In 2015, based on BPS, the sugar cane production is $1,231,726$ tons, which is around $48.87 \%$ of the total Indonesian sugarcane production. The other production center of sugarcane is in Lampung Province. Lampung Province as the second largest sugarcane produces about 756.5 thousand tons or about $29.81 \%$ of total production in Indonesia. It can be seen in Figure 1.

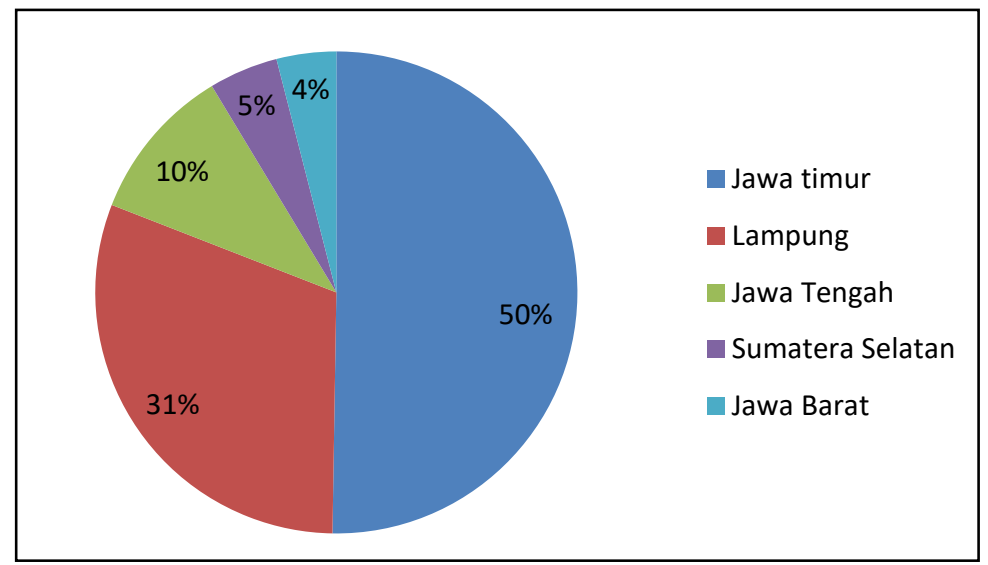

Figure 1. Central of Sugarcane in Indonesia

Government participation in East Java to strive to increase sugarcane production and productivity and support success National Sugar SelfSufficiency Program, carried out supporting activities namely the National Sugar Productivity Increased Acceleration Program since 2001. The rehabilitation activities of this sugar cane plant use superior sugarcane seedlings by replacing the 28,000 Hectare old sugarcane variety owned by farmers. The implementation of this activity began in 2003 with the replacement of varieties through the construction of nursery and unloading Ratoon. The construction of sugarcane nurseries was carried out in stages, where from 2003 to 2005 replacement was carried out for 8,634 hectares. Whereas the realization of ratoon unloading activities in East Java starting from 2003 to 2005 reached 97,135 hectares.

Sugarcane plantations are spread in almost all districts/cities in East Java Province, which include Malang, Kediri, Mojokerto and Jombang. The amount of sugarcane production produced by the five regencies is the largest number among other districts in East Java with the contribution to sugar production in East Java Province reaching 56.65\% (BPS East Java Province, 2016).
Malang Regency is one of the biggest sugarcane-producing districts in East Java which ranks first. According to the Central Bureau of Statistics of East Java Province in 2016, Malang Regency recorded producing 224,357 tons (25.4\%) of sugar cane production in East Java Province. The next largest sugarcane producer district is Kediri Regency with a production of 150,387 tons (15\% of sugar cane production in East Java Province), Lumajang District with a production of 100,885 tons $(6.45 \%)$, Mojokerto Regency at 52,090 tons $(5.04 \%)$, and Regency Jombang with production reaching 49,227 tons $(4.73 \%)$. This shows that Malang Regency has potential in sugarcane farming so that it can increase the production and productivity of sugar cane by using efficient production factors.

Determinants of the success of sugarcane farming include the right and proper cultivation techniques. Sugarcane farming, that is intensively planted, watered, and a good cropping system, is expected to increase sugarcane production. Based on the description previously stated, it is necessary to have a study to analyze the level of technical efficiency of sugarcane farming in Malang Regency. With the hope that farmers are able to 
allocate production factors efficiently in order to increase production and productivity.

\section{RESEARCH METHODS}

Determination of the location of the study was done purposively in Malang Regency, East Java Province. The location was chosen considering that Malang Regency is one of the largest sugarcane production centers in East Java. This research was conducted from September to October 2016.

The object of the study was all sugarcane farmers in Malang Regency. The determination of the study area was carried out by the method of multiple stage sampling, where multiple stage sampling the complex form of cluster sampling. The multiple stage sampling method is a method in which sampling is carried out in stages based on existing regions (Singarimbun, 2008). The research area in this study was Krebet Village and Gondanglegi Kulon Village.

The first stage is to determine the sample subdistrict where from 33 sub-districts in Malang Regency 2 sub-districts are selected as samples. The selection was carried out intentionally or purposively, two sub-districts were chosen, namely Bululawang and Gondanglegi Districts with the consideration that the two sub-districts were sugarcane production centers in Malang Regency.

The second stage, with the selection of 2 sample villages namely Krebet Village for Bululawang District and Gondanglegi Kulon Village for Gondanglegi District with the consideration that the two villages have the potential for sugarcane farming which has a large area of land that is planted with sugar cane and many farmers cultivate sugar cane.

The third stage is the determination of samples from each village. Determination of the sample using simple random sampling method is the process of selecting a sample where all members of the population have the same opportunity to be chosen. Members of the population are chosen one at a time randomly, ie if the sample has been chosen, it cannot be selected again.

The next step is to calculate the number of research samples to measure the value of population variance $\left(\sigma^{2}\right)$, the formula used as follows (Parel, et al., 1973):

$$
\sigma^{2}=\frac{\sum\left(X_{i}-\bar{X}\right)^{2}}{n}
$$

After using the formula above, the population variance value $(\sigma 2)$ for Krebet Village is 0.97 while the population variance value for Gondanglegi Kulon village is 0.34 . Then the calculation of samples in the village of Krebet based on the population of sugarcane farmers is 90 farmers. Based on these calculations, a sample was obtained in Gondanglegi Kulon Village for 39 farmers.

Collection of data types in this study consists of two types, including primary data and secondary data. This primary data collection method is carried out by means of, namely: interviews, observation, and documentation.

An interview is a method used to collect data by conducting question and answer directly with sugarcane farmers. This method is carried out with a questionnaire, which is a list of questions proposed by the researcher relating to the title of the research in order to obtain the data needed. The data taken is about the characteristics of farmers such as age, formal education, number of family members, the area of land owned, then the production factors used by farmers in supporting the production process from the costs incurred by farmers to the production obtained by farmers in one farming season.

Observation is one method of collecting data with direct observation activities in the field regarding activities that occur, including daily routines or activities related to research. In this research activity, researchers emphasize the truth of how many factors of production (input) are used in the sugarcane farming process.

Documentation is a data collection technique through documents or archives from parties related to research, where the document can be used as evidence in research. Information can also be obtained in other forms such as photo files, letters, diaries, and so on. In this research can be taken such as data files from sugar cane production, data on capital borrowing, use of fertilizers and so on.

Whereas secondary data is data obtained through literature, previous research and related institutions or agencies that are used as complementary and supporting data from field results obtained or derived from primary data. Secondary data is obtained by directly taking the data available in the Department of Agriculture. The data used are area and land use, sugarcane production and the number and distribution of population. 
The analytical method used in this study is the analysis of stochastic frontier production function (SFPF). Border stochastic production is a production model introduced separately by Aiger, Lovell and Schmidt (1977) and Meesen and Van den Broeck (1977) in (Coelli, et al., 2005). The stochastic frontier model is an extension of the initial deterministic model to measure unexpected effects (stochastic effects) within the production limit. The production frontier model is thought to use MLE (Maximum Likelihood Estimation) using the frontier computing program version 4.1. MLE is used for the (overall) parameters either limited or unlimited. This MLE estimation method is to show the level of residue achieved in the model and efficiency and inefficiency in the OLS model (Coelli, 1998). The factors that influence the production of sugarcane farming in Malang Regency are the number of seeds, the amount of labor, the amount of fertilizer, and ratooncane. From the estimation model of frontier production function equation model from sugar cane farmers can be written as follows:

Ln $Y=\beta_{0}+\beta_{1} \ln X_{1}+\beta_{2} \ln X_{2}+\beta_{3} \ln X_{3}+\beta_{4} \ln X_{4}+$ $\beta_{5} \ln \mathrm{X}_{5}+\left(\mathrm{v}_{\mathrm{i}}-\mathrm{u}_{\mathrm{i}}\right)$

Where:

Y : Sugar cane productions (quintal)

$\beta_{0}:$ Intersept

$\beta_{1}$ : Estimated coefficiencts parameters

$\mathrm{X}_{1}$ : The amount seed (quintal)

$\mathrm{X}_{2}$ : The amount labor (labor days)

$\mathrm{X}_{3}$ : The amount fertilizer (quintal)

$\mathrm{X}_{4}$ : The amount land area (hectare)

$\mathrm{X}_{5}$ : Ratooncane (time)

$\mathrm{v}_{\mathrm{i}}$ : effect of technical inefficiency (model)

$\mathrm{u}_{\mathrm{i}}$ : Random variable

Hypothesis testing is carried out to test the output of the production function. . Hypothesis testing for the output of the production function is done by using the estimated parameter parameter $\beta$ to see whether there is any influence of each independent variable in the production function model.

a. Parameter hypothesis

$\mathrm{H} 0: \beta \mathrm{i}=0$

$\mathrm{H} 1: \beta \mathrm{i} \neq 0$

The null hypothesis means that the coefficients of each variable in the production function model are equal to zero. If this hypothesis is accepted, then each independent variable in the production function model has no effect at all on sugarcane production. So there is no real influence between each seed variable, labor, fertilizer, land area and number of crabs on sugarcane production.

The statistical test used is: If t-count> t-table, then reject $\mathrm{H} 0$ accept $\mathrm{H} 1$, meaning the variable number of seeds, number of workers, amount of fertilizer, amount of land area, and number of keprasan significantly influence sugarcane production. If $\mathrm{t}$ count $<\mathrm{t}$-table, then accept $\mathrm{HO}$ reject $\mathrm{H} 1$, meaning that the variable number of seeds, amount of labor, amount of fertilizer, amount of land and number of pieces does not significantly influence sugarcane production.

\section{b. Sigma-square and Gamma}

According to Coelli (1996), Pascoe (2003), and Coelli et all. (2005), stated that the sigma-square $(\sigma)$ value shows the variation of the observation value to the frontier value. If the sigma-square value $=0$ means that the input operates at the frontier point, while sigma-square $>0$ then there is a difference in the frontier value and the real value. Sigma-square value in frontier analysis is the sum of inefficiency effects and random error effects.

$$
\sigma^{2}=\sigma_{v}^{2}+\sigma_{u}^{2}
$$

Gamma $(\gamma)$ shows the presentation of the error composite value (error) caused by the technical inefficiency component. Mathematically written as follows:

$$
\gamma=\frac{\sigma_{u}^{2}}{\left(\sigma_{u}^{2}+\sigma_{v}^{2}\right)}
$$

\section{c. Likelihood Ratio Test}

The hypothesis which states that sugarcane farming has not been technically efficient needs to be tested using the Likelihood Ratio Test. The Likelihood Ratio Test is a hypothesis test to test a farm that is technically efficient by comparing the LR value.apdratheecitingapothasses of $X^{2}$ (in the Kodde and Palm Table). The hypothesis can be expressed in the following equation:

H0: $L R=0$ (no inefficiency effect)

$\mathrm{H} 1: \mathrm{LR}>0$ (there is an inefficiency effect) 
The null hypothesis $(\mathrm{H} 0: \mathrm{LR}=0)$ means that the coefficient of each variable in the efficiency effect model is equal to zero, it can be said that farming is $100 \%$ technically efficient. Whereas the accepted hypothesis H1: LR> 0) means that each independent variable in the model has an efficiency effect that has an influence on the level of efficiency in the production process so that the farming done still has opportunities for improvement.

\section{RESULT AND DISCUSSION}

The data obtained were analyzed by quantitative and qualitative methods. The quantitative method is used to analyze technical efficiency in sugarcane farming, identify technical efficiency for each respondent and find out the factors influencing the level of technical efficiency of sugarcane farming.

In this study using the production function stochastic frontier to find out what factors of production affect frontier production and how the level of technical efficiency achieved by each respondent farmer. Sugarcane production is influenced by seedlings $\left(\mathrm{X}_{1}\right)$, labor $\left(\mathrm{X}_{2}\right)$, fertilizer $\left(\mathrm{X}_{3}\right)$, land area $\left(\mathrm{X}_{4}\right)$, and ratooncane $\left(\mathrm{X}_{5}\right)$. The production function model used is:

Ln output $=\beta 0+\beta 1 \ln$ seed $+\beta 2 \ln$ labor $+\beta 3 \ln$ fertilizer $+\beta 4 \ln$ land area $+\beta 5 \ln$ ratooncane $+v i-$ ui

The result of estimation of stochastic frontier production function with MLE (Maximum Likelihood Estimation) can be seen in Table 1.

Table 1. Stochastic frontier production function

\begin{tabular}{|c|c|c|c|c|c|}
\hline \multirow{2}{*}{ Variable } & \multirow{2}{*}{ Parameter } & \multicolumn{4}{|c|}{ MLE (Maximum Likelihood Estimatiton) } \\
\hline & & Coef. & Standard Error & $\mathrm{T}-\mathrm{Sta}$ & \\
\hline Intersept & $\beta_{0}$ & 4,533 & 0,466 & 9,7273 & $* * *$ \\
\hline Seeds & $\beta_{1}$ & 0,2823 & 0,0762 & 3,704 & $* * *$ \\
\hline Labor & $\beta_{2}$ & $-0,0901$ & 0,0563 & $-1,596$ & * \\
\hline Fertilizer & $\beta_{3}$ & 0,6457 & 0,0677 & 9,5418 & $* * *$ \\
\hline Land area & $\beta_{4}$ & 0,1726 & 0,094 & 1,8368 & ** \\
\hline Ratoon-cane & $\beta_{5}$ & $-0,0415$ & 0,0557 & $-7,383$ & $* * *$ \\
\hline Sigma Squared & $\sigma^{2}$ & 0,1719 & 0,0602 & 2,8548 & $* * *$ \\
\hline Gamma & $\gamma$ & 0,4703 & 0,3471 & 1,3552 & $*$ \\
\hline
\end{tabular}

Log Likelihood Function $=46,3967$

LR test of the one-sided error $=3,666$

t-table: 2,616 (*** significant at alpha 1\%)

t-table: $1,657(* *$ significant on alpha $10 \%)$

t-table: 1,288 (*significant on alpha $20 \%$ )

Source: Primary Data, 2018 (Processed)

The estimation results of the stochastic frontier production function using the MLE (Maximum Likelihood Estimatiton) approach in Table 1. Sigma-square $\left(\sigma^{2}\right)$ and gamma $(\gamma)$ values obtained from the estimation using the MLE method are 0.172 and 0.47 . In the study, the value $(\sigma)$ which is greater than zero indicates that there is an influence of technical inefficiency in the production function model. While the gamma $(\gamma)$ value shows that the variation in composite values is an error caused by a component of technical inefficiency (Coelli, 1998). Gamma $(Y)$ value of 0.47 indicates that an error or error caused by technical inefficiency is $47 \%$. This shows that there is a difference between actual production and maximum production, which is more due to the presence of technical inefficiency effects, while the remaining $53 \%$ is caused by random error variables such as weather, pest attacks or modeling errors.

To find out whether all sugarcane farmers do farming in technical efficiency can be known by using the Likelihood Ratio Test (LR) test. Hypothesis testing was carried out in this study by using the estimation results of Likelihood Ratio Test (LR) using software frontier 4.1. LR test value in frontier results using the MLE method of 3.666. The LR test results are then compared with the 
values (Kodde and Palm, 1986) with a number of restriction of 1 with a $95 \%$ confidence level of 2,706. After being compared, it was found that the LR test value was greater than the critical value, obtained by the coefficient value of each variable in the model the inefficiency effect was not equal to zero. Then each independent variable in the inefficiency effect model has an influence on the level of inefficiency in the production process of sugarcane farming. This proves that the frontier production function is able to properly explain the existing data regarding the occurrence of technical inefficiency phenomena in sugarcane farming. This means that sugar cane farmers in the study area are not yet fully efficient in carrying out sugarcane farming.

The results of calculations in Table 1 show the influence of each factor of production on sugarcane farming production. Discussion of the estimation results of the frontier estimation will be discussed in more detail as follows:

1. Factors affecting sugarcane production in Malang Regency

a. Seeds

The value of t-count in the seed factor is 3.704 , where the $\mathrm{t}$-count is greater than the $\mathrm{t}$-table, which is 3.704> 2.616, so the seed factor has a significant effect on sugarcane production in the study area with a $99 \%$ confidence level. The value of the coefficient on the use of seeds has a positive sign and the amount is 0.282 , indicating that increasing the use of seeds by $1 \%$ will increase production by $0.282 \%$, as well as reducing the use of seeds by $1 \%$ will reduce production by $0.282 \%$.

The influence of seedlings on sugarcane production is due to the fact that in the study area using superior seeds include Bululawang varieties, PS 881, PSBM 901, and PSJK 922. According to Kusuma, 2010, superior seeds that have been released by the Ministry of Agriculture and have been legalized like BL varieties (Bulu Lawang), Kentung variety, PS 851 variety, PS 951 variety, PS 684, PS 865, Triton variety, PSJT variety, VMC 7616 variety, PSJT 941 variety, PSCO 902 variety, PSPM 901 variety, etc. In addition (Tunjungsari, 2014) these types are seed varieties that have been tested by the government with high production. If the variety is cultivated according to the government's recommendation, it will cut down the optimal cooking conditions. That is at the age of 10-12 months under SBM conditions (Cook, Clean, and Healthy) so that a significant increase in production will be achieved. The influence of seeds on the next sugar cane production is in the process of planting sugar cane which is not normal growth, such as seeds that do not grow buds, the sugar cane must be replaced which means more seeds are used, so as to maintain sugarcane production.

In addition to the use of seed varieties used by farmers, in the study area the average use of seedlings of the respondent farmers was 84.08 quintal/hectare. While the recommended use of sugarcane seeds from extension workers is $80-100$ quintal/hectare.

b. Labor

The t-count value on the labor factor is 1,596, where the $t$-count value is greater than the $t$-table which is $1,596>1,288$, so the labor factor has a significant effect on sugarcane production in the study area with a confidence level of $80 \%$. Coefficient value on the use of labor has a negative sign and the magnitude is 0.09 , indicating that an increase in the use of labor by $1 \%$ will reduce production by $0.09 \%$, as well as a reduction in labor use of $1 \%$ will increase production by 0.09 $\%$.

In sugarcane farming in the research area labor activities start from the process of land cultivation, seeding, planting, planting, planting, irrigation, fertilization, weeding, klentek, up to harvest, where it will affect sugarcane production. In sugarcane cultivation in the research area, harvesting activities are cutting down sugarcane stems and then cleaning from the soil, roots, shoots, dried leaves and dirt. At harvest activities are always carried out simultaneously by all farmers who have been determined by the factory officer. Because these harvesting activities are carried out simultaneously, causing farmers to need additional labor from outside the sub-district to help harvest activities. For an area of 1 hectare on average requires a workforce of 28.18 labor days.

If the labor used is more than 28.18 labor days, the harvesting activities carried out by loggers are not optimal, in other words, the workforce cuts down sugarcane stems without seeing the criteria for ready-to-grind sugar cane received by the factory. Therefore the use of labor affects the production of sugar cane.

c. Fertilizer 
The t-count value in the fertilizer factor is 9.542 , where the $t$-count value is greater than the $t$-table of 9.542> 2.616, so the fertilizer factor has a significant effect on sugarcane production in the study area with a $99 \%$ confidence level. Coefficient value on the use of fertilizer has a positive sign and the amount is 0.646 , indicating that an increase in fertilizer use by $1 \%$ will increase production by $0.646 \%$, as well as a reduction in fertilizer use by $1 \%$ will reduce production by $0.646 \%$.

The response of plants to fertilizer application will increase if the fertilizer used is the right type, dose, time and method of use. In the study area fertilizers on sugarcane crops each type of different types and doses are urea fertilizer of 7.22 quintal/hectare, ZA fertilizer of 10.01 quintal/hectare, Ponska fertilizer of 6.01 quintal/hectare, and Petroganic fertilizer amounting to 21.32 quintal/hectare. This shows that these four types of fertilizer need to be increased to increase sugarcane production, especially Petroganic fertilizers, because these fertilizers include manure which is very good for soil fertility and to restore nutrients in the soil. So that if farmers add fertilizer factors will increase sugarcane production.

\section{d. Land area}

The t-count value on the factor of land area is 1,837 , where the $\mathrm{t}$-count value is greater than the $\mathrm{t}$ table that is $1,837>2,616$, so that the land area factor significantly influences sugarcane production in the study area with a 90\% confidence level. Coefficient value on the use of land area has a positive sign and the amount is 0.173 , indicating that an increase in land use by $1 \%$ will increase production by $0.173 \%$, as well as a reduction in seed use by $1 \%$ will reduce production by $0.173 \%$.

The influence of land area on sugarcane production is caused by the condition of the land in the research area which is very suitable for sugarcane cultivation. In the research area of farmers who have a land area between 0-2 hectare used for the most sugarcane farming, that is $94 \%$. While the number of farmers, who have land area between $2.1-4.0$ hectares, is $4 \%$ and the land area is between $4.1-6$ hectares by $2 \%$, while the land area $>6.1$ Hectare is $1 \%$. So that if farmers add land area factors will increase sugarcane production.

\section{e. Ratooncane}

The t-count value on the ratooncane factors was 7.383 , where the $\mathrm{t}$-count was greater than the $\mathrm{t}$ table, which was 7.383>2.616, so that the factor of total number of factors had a significant effect on sugarcane production in the study area with a confidence level of $99 \%$. The coefficient value on the ratooncane has a negative sign and the magnitude is 0.042 , indicating that an increase in the ratooncane by $1 \%$ will reduce production by $0.042 \%$, as well as a reduction in the ratooncane by $1 \%$ will increase production by $0.042 \%$.

This is because the sugarcane crushing plants should be harvested a maximum of 3 to 4 times ratooncane, but in the field conditions, there are farmers respondents who make the ratooncane up to 4 times as many as 109 farmers. This result is the same as the research conducted by Lestari (2015) in Purnamasari (2018), that the more ratooncane of sugarcane varieties indicates that the level of inefficiency in sugarcane farming is higher. This is because sugar cane in the early stages has a high weight and yield value, which, based on the Directorate General of Plantation (2015), the decrease in weight and yield of sugar cane is caused by farmers' understanding of sugarcane planting systems. So, the addition of the number ratooncane will affect the farmers' production.

\section{CONCLUSION}

Based on the results of the analysis carried out, it can be concluded, namely: production factors that have a significant and positive effect on sugarcane production in Malang Regency are variable seeds, fertilizer and area. While the factors of production that have a significant and negative effect on sugarcane production in Malang Regency are the number of consumers and labor. Stochastic frontier production function analysis model which has been tested with MLE (Maximum Likelihood Estimation) is declared valid, seen from the sigmasquare $(\sigma)$ value which is greater than zero and the gamma $(\gamma)$ value is 47 percent.

\section{REFERENCES}

Central Data Statistics Republic Indonesia. 2017. Production of Sugar Cane by Regency/City in East Java Province. Surabaya.

Central Data Statistics Republic Indonesia. 2015. Indonesian Sugarcane Statistics. Jakarta. 
Coelli, T.J., D.S. Prasada. Rao, and G.E. Battese. 1998. An Introduction to Efficiency and Productivity Analysis. Kluwer Academic Publishers. .London.

2005. An Introduction to Efficiency and Productivity Analysis. Kluwer Academic Publishers. .London.

Plantation Agency in East Java. 2016. National Sugar Self - Sufficiency Enhancement Acceleration Program. Surabaya.

Farrel, M. J. 1957. The Measurement of Productive Efficiency. Journal of the Royal Statistical Society. Series A, CXX, Part 3.

Kusuma, A. 2010. Management of Sugarcane (Saccharum officinarum L.) Dryland at PT. White Sugar Mataram, Lampung: Case Study of Frequency of Flushing. Essay. University of Bogor Agricultural. Bogor.
Singarimbun, Masri and Sofian Effendi. 2008. Survey Research Methods, LP3ES: Jakarta.

Tunjungsari, Ratna. 2014. Analysis of Sugarcane Production in Central Java. Trail 7 (2): 100-202.

Parel, C. P., G. C. Caldito, P. L. Ferre, G. G. de Guzman, C. S. Sinsioco, and R. H. Tan. 1973. Sampling Design and Procedures. PSSC. Phillipine.

Purnamasari, I. 2018. Technical Efficiency Analysis of Sugar Cane Farming in East Java Indonesia (Statistical Approach of Frontier Production Functions). Agricultural SocioEconomics Journal. 18 (1): 23-29.

Lestari, E. K. 2015. Efficiency and Framework for Institution of People's Sugarcane in Supporting Regional Economy in Jember Regency. Dissertation. Postgraduate. Bogor Agricultural Institute. Bogor. 